\title{
Glossary, acronyms and abbreviations
}

\author{
accounting officer senior civil servant responsible to the UK parliament \\ for the stewardship of resources. Canada also uses \\ a variation on the concept \\ agencification \\ creation of semi-autonomous agencies as part of \\ a disaggregation process \\ agency \\ used as an alternative to 'department' and in oth- \\ er contexts might encompass departments and \\ non-departmental organisations \\ $\mathrm{AO}$ \\ accounting officer \\ $\operatorname{APS}(\mathrm{C})$ \\ Australian Public Service (Commission) \\ AU \\ Australia (abbreviation) \\ Barber, M. architect of UK's implementation unit and advisor to \\ governments \\ BASS \\ Administrative and Support Services Benchmarking \\ (NZ) \\ BPS \\ Better Public Services, a priority-driven reform \\ initiative originating in the NZ Better Public Services \\ review (BPSAG 2011) \\ bureaucratisation \\ reliance on controls, rules and regulation, and pro- \\ cesses and procedures \\ CA \\ Canada (abbreviation) \\ CAG \\ Comptroller and Auditor General (UK) \\ central agency \\ cross-government agencies at the centre \\ CEO \\ civil service \\ core executive \\ chief executive officer \\ used in the UK. The preferred term elsewhere is \\ 'public service' \\ components of government and their relationships; \\ narrow and broader versions in use (UK) \\ CPA Committee of Public Accounts (UK) \\ CSC Civil Service Commission (UK)
}




\begin{tabular}{|c|c|}
\hline DBP & departmental business plan (UK) \\
\hline delegation & $\begin{array}{l}\text { assignment of responsibilities from one level to } \\
\text { another }\end{array}$ \\
\hline department head & $\begin{array}{l}\text { generic term for chief executive officers (NZ), depart- } \\
\text { mental secretaries (AU), deputy ministers (CA), and } \\
\text { permanent secretaries (UK) }\end{array}$ \\
\hline dept & department \\
\hline deputy minister & head of department in Canada \\
\hline devolution & $\begin{array}{l}\text { used by reformers in Australia and New Zealand: 'the } \\
\text { transfer of decision-making capacity from higher lev- } \\
\text { els in the organisation to lower levels' (TFM1 1992, } \\
\text { p. 89), and was applied to transfers from central agen- } \\
\text { cies to departments and within departments }\end{array}$ \\
\hline DoF & Dept of Finance (AU) \\
\hline DPMC & $\begin{array}{l}\text { Department of the Prime Minister and Cabinet (AU, } \\
\text { NZ) }\end{array}$ \\
\hline exempt staff & Canadian term for staff appointed by a minister \\
\hline Finance & Department of Finance (AU) \\
\hline FMI & Financial Management Initiative (UK) \\
\hline FMIP & Financial Management Improvement Program (AU) \\
\hline GFC & global financial crisis \\
\hline $\begin{array}{l}\text { Gomery } \\
\text { Commission }\end{array}$ & $\begin{array}{l}\text { Inquiry into 'sponsorship scandal', with accountabili- } \\
\text { ty focus (CA) }\end{array}$ \\
\hline $\mathrm{HC}$ & House of Commons \\
\hline IDC & interdepartmental committee \\
\hline IMAA & $\begin{array}{l}\text { Increased Ministerial Authority and Accountability } \\
\text { (CA) }\end{array}$ \\
\hline KPI & key performance indicator \\
\hline MAC & Management Advisory Committee (AU) \\
\hline MAF & Management Accountability Framework (CA) \\
\hline Manzoni, J. & CEO of the UK civil service \\
\hline Maude, F. & $\begin{array}{l}\text { Minister for the Cabinet Office in the Cameron gov- } \\
\text { ernment (UK) }\end{array}$ \\
\hline
\end{tabular}


ministry

MRRS

NAO

No. 10

NPG

NPM

NZ

OAG

OPA

PBE

PCO

PF2

PFI

PGPA

PI

PIF

PMD

PMDU

PMO

PMS

PPP

PRAS
The term co-exists with departments in NZ and for some agencies in the UK. The term department covers both

Management, Resources and Results Structure (CA)

National Audit Office (see CAG)

Downing Street, Prime Minister's Office (UK)

new political governance

new public management. A slippery concept because of loose applications. It is mainly used here in the narrower sense of a reform programme emphasising boundaries and external actors

New Zealand (abbreviation)

Office of the Auditor General (CA)

Output and Performance Analysis (UK)

policy-based evidence (as opposed to EBP:

evidence-based policy)

Privy Council Office (CA)

Private Finance 2 (UK)

Public Finance Initiative (UK)

Public Governance, Performance and Accountability Act 2013 (AU)

performance information

performance improvement framework (NZ)

prime minister's department. A generic term that covers the Australian and New Zealand Department of the Prime Minister and the Cabinet (DPMC), the Canadian Privy Council Office (PCO), and the UK Cabinet Office (CO)

prime minister's delivery unit (UK)

prime minister's office, a term in standard use across the four

public management system

public-private partnership (UK)

Planning, Reporting and Accountability Structure (CA) 


$\begin{array}{ll}\text { PSA } & \text { Public Service Agreement (UK) } \\ \text { PSC } & \text { Public Service Commission } \\ \text { red tape } & \text { excessive reliance on regulations and bureaucracy } \\ \text { reform era } & \text { early 1980s until the present } \\ \text { SCS } & \text { senior civil service (UK) } \\ \text { SDP } & \text { single departmental plan (UK) } \\ \text { SES } & \text { senior executive service } \\ \text { SOA } & \text { special operating agencies (CA) } \\ \text { SOI } & \text { statement of intent } \\ \text { spad } & \text { special adviser (UK) } \\ \text { Spending Review } & \text { a process run by the UK Treasury every few years for } \\ \text { SSC } & \text { setting expenditure limits and planning } \\ \text { TBS } & \text { State Services Commission, a leading central agency } \\ \text { TPA } & \text { in New Zealand } \\ \text { UK } & \text { Treasury Board of Canada Secretariat } \\ & \text { traditional public administration } \\ & \text { United Kingdom (abbreviation) }\end{array}$


John Halligan - 9781839107498 Downloaded from PubFactory at 04/26/2023 03:10:14PM via free access 